\title{
Spoken Errors of Malay Language among Rohingya Learners: A Case Study in Pelangi Kasih School
}

\author{
Madya Dr. Faridah Binti Nazir, Professor, International Islamic University Malaysia. E-mail: fidafn@iium.edu.my
}

Zanariah Binti Jano, Melaka Technical University Malaysia.E-mail: zanariah.jano@utem.edu.my

Balqis Binti Senawi, International Islamic University Malaysia. E-mail: qies2594@gmail.com

\begin{abstract}
This study was conducted to identify the characteristics of spoken errors in Malay language and determine the factors of the errors made among the Rohingya pupils in the Pelangi Kasih School, a nongovernmental organization run by the United Nations High Commissioner for Refugees (UNHCR), also known as the UN Refugee Agency. The methods employed were research desk, field experiment, interviews and observation in Malay and Math classes. The findings yielded that the common errors made were in the usage of abbreviations, prepositions, code-mixing, affixes and auxilliaries. The factors of committing the errors were attributed to three; ignorance, environmental and language interference. This study is beneficial for the UNCHR and school teachers in planning effective interventions to curb the problems of acquiring Malay language among the refugee students.
\end{abstract}

Keywords--- Spoken Language, Errors, Rohingya, Pelangi Kasih School, UNHCR.

\section{Introduction}

As of end-April 2019, about 90,200 Rohingya refugees were registered with the United Nations High Commissioner for Refugees (UNHCR) in Malaysia. Children are the dominant group. These Rohingya refugee children have been discriminated against in the education sector as they are not as privileged to receive a formal education as other children. The Malaysian policy does not address inclusivity of undocumented migrants, hence, refugees do not have access to essential needs such as legal employment, formal education and free healthcare (Letchamanan, 2013). Moreover, the cost of private education is often too expensive to be borne by the community. Lacking of education makes thousands of Rohingya children being exposed to human trafficking, social problems and illiteracy. The article should be between 15-20 pages (not more than 7000 words), single-spaced, 10 point Times New Roman font, excluding references and appendices. Use no indent for the first paragraphs and do not leave a space between paragraphs.

\section{Statement of Problem}

The myriad of barriers in the form of security and protection issues is due to the lack of legal status; language and cultural differences with the host population (Puras, 2015). In addition, the Rohingya refugee children who are studying in Malaysia are required to learn the language. This is because language is an essential communication tool to interact with others. However, a number of factors might cause a poor command of Malay language among them, partly because Rohingya students only speak their native language, the Burmese and Rohingya language. The lack of literature in studying the language aspects of Rohingya students has prompted this study to be conducted.

\section{Research Objectives}

This study has two objectives as follows:

a) Identify features of language error in the speech of Rohingya students.

b) Determine the factors causing the language error in the Rohingya pupils' speech.

\section{Literature Review}

According to the Kamus Dewan Edisi Ketiga (1994), the analysis of linguistic errors refers to the decomposition of a matter to determine its good and bad origin, or to study a wrong act or anything wrong grammatically that is used by a person in speech or writing. This statement was further reinforced by Corder (1990: 62), stating that everyone who learns the language will always commit errors (Noor Aziah, 2004). Some aspects of common language errors are as follows: 


\section{a) Word Error Aspect}

Word error involves morpheme aspects. A morpheme is a meaningful linguistic unit consisting of a word. Morpheme errors might be committed through the wrong usage of affixes and words.

\section{b) Syntax Errors}

Syntax refers to sentence structure. It is a branch of linguistics that studies verse form, sentence structure, and sentence construction. Syntax not only examines the process of sentence construction but also the laws that determine how words are arranged in a sentence. Syntax errors include sentence fragments, sentence sprawl, misplaced and dangling modifiers and faulty parallelism, unclear pronoun reference.

Language error analysis is a technique for studying and learning the language skills of students by classifying each mistake they make. (Hartman and Stock, 1972). In addition, Ollerdan Richards (1972) and Corder (1972), described the analysis of this language error as, "dealing with the differences between the way people learning a language speaks and the way adult native speakers of the language use the language". In short, language error analysis is a method of solving the problem of handling a language consisting of a second language, a mother tongue, or a target language.

\section{Rohingya and Burmese languages}

The development of the Rohingya language is the most vital issue. This situation occurs because the Rohingya language is the result of a mixture of different languages. This language has been developed for over a thousand years. The official language of Arakan had been Persian since the time of the early Mrauk-U kings until 1845, 22 years further dominating the Arakan conquest by the British. During Mrauk-U relations, Benggal was well known for his prolific Bengali literature which reached the Arakan Court.

Many renowned poets who had served the Arakan kings such as Shah Alawal, Daulat Qazi, and Magan Siddiqi wrote in Persian and Arabic or in the mixed language, Rohingya, which is a mixture of Bengali, Persian, Arabic, and Arakanese (Rakhaing). However, the Rohingya language was widespread during the time of the Arakan Emperor. Its status as a written language has been abolished as it was largely destroyed by the Burmese invaders in 1784 and was no longer maintained by subsequent colonizers. The spoken language of Maghs-Maghi or Rakhaing is not a separate language but a native Burmese language with phonetic variations. No Rakhaing languages are written separately.

The question of the emergence of the Arakanese (Rakhaing) language is more difficult. Whether this was the language of the Mongolian invaders in the 10th century or the language refined across the mountains after they came into contact with the Burmese in the 11th and 12th centuries was hard to be determined. The Arakanese (Rakhaing) language is very similar to the Burmese language, the only difference is their dialect. If so, the Arakan language is considered a colonial language. It means that colonists had previously thought that Chandras used the same language as other leaders in the Irrawady area. However, it is formulated and argued that the Burmese language actually came from the mountains. Later, the Burmese people tried to convert the Arakan language into a modern Arakan language. This is where the difficulties in linguistics are faced. This question has yet to be resolved (Mohd Yunus, 1994). In a nutshell, Rohingya lacks a universally accepted script, hence, Burmese is the preferred language for written communication.

\section{III.Method}

This study adopted a qualitative method. The data were collected by means of research desk, field experiment, interviews and participant observation in Malay and Mathematic classes.

\section{Respondents}

Four students, two boys and two girls, were monitored to identify language error characteristics in their speech on $16^{\text {th }}$ July 2019 during Mathematic class. On 1st November 2019, the second data collection was conducted in the Malay language involving two males and two female students.

\section{Instruments}

The instrument used in this study is language diary and spontaneous recording during the participant observation method. 


\section{Procedures}

On July 16, 2019, data were collected in the Mathematic class through participant observation method. Four students, two boys and two girls, were monitored to identify language error characteristics in their speech. Whereas on 1st November 2019, the second data collection was conducted in the Malay language class through observation method. Two males and two female students were being observed to ascertain the characteristics of the language errors in the students' utterances.

\section{Data Analysis}

All data collected were analyzed manually through the qualitative method using appropriate tables.

\section{IV.Findings and Discussion}

This section discusses the findings for the first objective namely, identifying characteristics of language errors in the speech of Rohingya pupils. The analysis was carried out through the transcriptions of the text from the observations and interviews recorded using smartphones.

\section{Features of Language Error in the Speech of Rohingya Students}

\section{The Teaching and Learning of Mathematics}

On July 16, 2019, data were collected in the Mathematic class through observation method. Four students, two boys and two girls, were monitored to identify language error characteristics in their speech.

\section{a) Errors in Abbreviation}

i) Abbreviations are often used to convey any intended message. However, their usage shows grammar violation. Abbreviation errors are committed not oly in oral but also written mode. The common errors made by students are as follows.

\begin{tabular}{|l|l|}
\hline Wrong version & Correct version \\
\hline$*$ Cikgu, ni nak buat cam na? & Cikgu, ini macam mana hendak buat? \\
\hline
\end{tabular}

ii) The following sentences illustrate the misuse of the 'how to' question that students often use to refer to the 'how' of doing something. In addition, abbreviated versions are mostly used in the sentence.

\begin{tabular}{|l|l|}
\hline Wrong version & Correct version \\
\hline *Macam mana nak buat? Macam mana nak buat? & Bagaimana hendak buat? Bagaimana hendak buat? \\
\hline *Cikgu, yang ni nak bahagi cam na? & Cikgu, bagaimana hendak bahagi yang ini? \\
\hline *Cikgu, tak faham. & Cikgu, tidak faham. \\
\hline
\end{tabular}

iii) Helping word in terms of aspect describes the time frame that a task is executed for example, whether a certain task is going to be performed, is being performed, has just begun,or has not yet performed. Helping words in terms of manner, present before the verb, explain the manner of a certain verb, i.e- someone must do it, intends, or able to do it. The following sentences are utilizing the verb has done (sudah). Sudah is shortened to dah. Besides, sudah can only be used once and not repeatedly. Moreover, the helping word of hendak uttered by a student is also included.

\begin{tabular}{|l|l|}
\hline Wrong version & Correct version \\
\hline *Dah agak dah & Sudah agak. \\
Saya dah letak dah. & Saya sudah letak. \\
\hline *Nak minum air. & Hendak minum air \\
\hline *Cikgu, bukan macam ni. & Cikgu, bukan macam ini. \\
\hline *Kena titik kat mana tah? Kat strawberi? & Di mana perlu letak titik. Di strawberi? \\
\hline
\end{tabular}

\section{b) Error in Sentence Structure}

In terms of sentence structure, the students made many errors. Ane error occurs when a student makes an enquiry to seek answers. This scenario might happen subconsciously.

\begin{tabular}{|l|l|}
\hline Wrong version & Correct version \\
\hline Cikgu, boleh tiru sini darab. & Cikgu, bolehkah nombor ini didarabkan? \\
\hline
\end{tabular}




\section{c) Error in Questioning}

Bagaimanakah and mengapakah are more properly used than kenapakah and macam manakah. If the question mark is placed in front of the sentence, then a particle kah must also be placed.

\begin{tabular}{|l|l|}
\hline Wrong version & Correct version \\
\hline Cikgu, yang ni nak bahagi cam na? & Cikgu, bagaimanakah hendak bahagi yang ini? \\
\hline
\end{tabular}

\section{d) Error in Affixes}

Prefixes are used to change a form. Men is used for a root word starting with c,d and $\mathrm{j}$. The following sentence shows a violation of rule when men is not inserted within the sentence.

\begin{tabular}{|l|l|}
\hline Wrong version & Correct version \\
\hline Setiap orang dapat $6 \mathrm{~K}$ & Setiap orang mendapat $6 \mathrm{~K}$ \\
\hline
\end{tabular}

\section{The Teaching and Learning of Malay Language}

On 1 November 2019, the second data collection was conducted in the Malay language class through observation method. Two males and two female students were being observed to ascertain the characteristics of the language errors in the students' utterances.

\section{a) Error in Word Formation}

The following sentence is uttered which violates the grammar rules.

\begin{tabular}{|l|l|}
\hline Wrong version & Correct version \\
\hline Saya tengah pikir. & Saya sedang fikir. \\
\hline Saya bagi pencil box ini & Saya beri pencil box ini \\
\hline
\end{tabular}

Pikir is not found in the website of Pusat Rujukan Persuratan Melayu (2019). Tengah and bagi are not an appropriate form to use to describe the act.

\section{b) Error in Abbreviation}

The following sentences show the violation of rules in the usage of abbreviation.

\begin{tabular}{|l|l|}
\hline Wrong version & Correct version \\
\hline Saya nak pergi ke KLCC & Saya hendak pergi ke KLCC \\
\hline Saya nak bagi buku ini kepada Umairah. & Saya hendak bagi buku ini kepada Umairah. \\
\hline Saya tak de. & Saya tidak ada. \\
\hline Cikgu, buku bahasa Melayu ada kat cikgu ke? & Cikgu, buku bahasa Melayu ada pada cikgu? \\
\hline
\end{tabular}

\section{c) Error in Preposition}

Incorrect use of the preposition of places dari and daripada occurs. While dari is used to indicate time, place, and direction, daripada is used to compare and ascertain the cause of something. In addition, an omission of a preposition often occurs as well. The following sentences show the wrong usage in preposition to indicate places and the non-omission.

d) Code-mixing

\begin{tabular}{|l|l|}
\hline Wrong version & Correct version \\
\hline Saya berasal daripada kampung. & Saya berasal dari kampung. \\
\hline Terletak masa awal ayat. & Terletak pada masa awal ayat. \\
\hline
\end{tabular}

Language code mixing is the use of more than one languages in a speech. As Nababan says, code mixing is a language state of the art in which a language user mixes one or more languages into one speech (Tan Kooi Yee, 2009). The following sentence shows a code mixing of Malay and English.

\begin{tabular}{|l|l|}
\hline Wrong version & Correct version \\
\hline Oh, no. & Oh, tidak \\
\hline Saya beri pencil box ini. & Saya bagi kotak pensel ini \\
\hline
\end{tabular}

\section{e) Error in Affixes}

Only two suffixes form the verb in Malay language namely kan and $i$. The suffix-i is used with verbs, nouns, adverbs and adjectives. The following sentence does not end with $\mathrm{i}$ after the prefix-me. The mistake made is that $i$ is not included in the sentence and there is no description of the way in which it is inserted. A description of a way 
that describes the style or act is missing in the sentence. Dengan (preposition) should be included to describe the act.

\begin{tabular}{|l|l|}
\hline Wrong version & Correct version \\
\hline Setiap hari Syahmi pergi sekolah menaik bas. & Setiap hari Syahmi pergi ke sekolah dengan menaiki bas. \\
\hline
\end{tabular}

\section{f. Error in WH Questions}

A WH question is a sentence that contains questions such as berapa, bagaimana, bila, kenapa, and mengapa. In the usual order, the query comprises a predicate element as in the following sentences and the insertion of kah before the question word.

\begin{tabular}{|l|l|}
\hline Wrong version & Correct version \\
\hline Mana Sudur dan Syahid? & Di manakah Sudur dan Syahid? \\
\hline Bila saya pergi ke sekolah? & Bilakah saya pergi ke sekolah? \\
\hline Mengapa saya ke sekolah? & Mengapakah saya ke sekolah? \\
\hline
\end{tabular}

In addition, the use of question words with a pronoun also creates a problem. This type of sentence comprises pronouns like siapa, mana, and apa. In the common order, the pronoun should be placed in the predicate section.

\begin{tabular}{|l|l|}
\hline Wrong version & Correct version \\
\hline Nombor tiga tu dia siapa tu? & Nombor tiga itu siapa? \\
\hline
\end{tabular}

\section{g) Error in Affirmative Word}

Affirmative word or particle is a word that give emphasis on certain part of a sentence. Kah is often being replaced with $k e$ to emphasize a certain utterance.

\begin{tabular}{|l|l|}
\hline Wrong version & Correct version \\
\hline Cikgu, buku bahasa Melayu ada kat cikgu ke? & Cikgu, buku bahasa Melayu ada kepada cikgukah? \\
\hline
\end{tabular}

\section{Factors Causing the Language Error in the Rohingya Pupils' Speech}

\section{Findings on the Factors of Committing Language Errors}

Based on interviews conducted with students from grade 8 Arif and Dynamics, there were a variety of causes that prevent foreign students from acquiring Malay language effectively. The findings show that there are three factors namely ignorance, environmental and language interference.

\section{Ignorance}

The attitude of the students who only interact among them will eventually makes them think that do not need to use the Malay language. They have their native language for communication purposes among them. Hence, the importance of the Malay language is neglected. Today, many of the vocabulary present reflects these symptoms. In the language study realms, these symptoms are known as language ignorance. Ignorance can also be seen when the Rohingya students cannot distinguish the structure of sentences and the correct vocabulary in Malay. The interference of their ntive language might be the case. Next, the findings of the ignorance can be seen when respondents were asked by the interviewer regarding their family members ability to speak the Malay language.

R1: "If not my mother, my dad can. I'm not sure about my siblings.

In short, the factor of ignorance might originate from family members that do not use English when communicating with each other. As a result, the new foreign students studying Malay language are not able to distinguish good Malay words or sentences.

\section{Environmental}

Another factor that influences the Rohingya students in using the Malay language is environmental.

"We use our native language at home and English is used only in school" (R 1,4, 6, 7,8) "

Usually neighbours speak in Rohingya." (R8)

In addition, the Respondents 2. 5,7, and 8 speak the language of Burmese / Myanmar in the respondents' homes. Only 1 respondent uses partly Burmese and Malay languages.

"Sometimes Myanmar. Sometimes the Malay language. "(R5) 
This study also coincides with the environmental factors faced by $\mathrm{R} 1,2,4,5,6,7$, and 8 . Their family members prefer their own mother tongue to communicate among family members. This scenario is emphasized by Abdul Sukor, Nuraini, Mohd Izam and Mohd Hasani (2011) who found that indigenous students are exposed to native language interference in their speech.However, respondent 3 prefers the use of languages other than the Rohingya language at home.

"Malay. I do not use Rohingya language" (R3)

\section{Language Interference}

Language interference is a phenomenon that results from the habit of inserting the mother tongue in a second language. Ali al-Khuli (1988: 91-92) explains that interference or al-Tadakhul refers to a situation of strong language dominance or a dominant language to one against a weak language. He added, the existence of two languages namely the native and target languages that are being processed in one's mind, could make the language most familiar to be dominant in one's new method of learning. In addition, another interfernce is in terms of old habit in which the native language inherited from childhood interferes and influences the form of a new habit or target language during the language learning process. This interruption will result in a language error known as interlingual error (Nor Asree, 2017). This error occurs when the respondents incline to move the character and structure of their native language into the target language during the learning process. This can be seen when respondents 7 and 8 uttered sentences in Myanmar to facilitate the researchers to see the different structure of sentences in their native language and Malay.

"Mak sudah makan nasi tak. Saya kena tolong apa? Mak, nak tidur tak?” (R7)

"Ibu masak tak? Ibu tulis tak? Ibu jaga anak ke?” (R8)

Based on the interviews with respondents 7 and 8, each sentence in Myanmar had a sentence structure that precede the sentence and end the sentence as well. It is clear through their spoken language that their native sentence structure will mainly affect their formation of Malay sentence structures.

\section{Discussion}

Overall, the analysis of the study is carried out based on the transcriptions gathered from observations and interviews of Rohingya students. The study is utilizing theories from Corder (1973) and Lutfi Abas (1987) which categorize eight types of linguistic factors, namely dialectic influence, foreign language influence, ignorance, psychological disorders, language disorders, grammar, language philosophy, and a collective theory. The adaptation of theories from literature has guided this study.

During the observations in selected classes, students often use abbreviations. In short, based on Corder Error Analysis (1973) theory, most students make mistakes in selecting incorrect abbreviations and prefixes which show that students often make mistakes that are unnecessary. This theory will enable teachers to keep track of mistakes made by students in school and facilitate correction. According to Bell (1981), language errors are intended to be in the form of speech that is not grammatical or structure of a language and this error arises as a result of imperfect control of the speaker's language system. In addition, language errors also refer to forms of execution weaknesses and occur accidentally or non-accidentally (Dulay et al., 1982 and Hammersly, 1982).

In terms of students'speech, most errors are caused by their limited use of Malay language. When they are with friends at school, no one will speak in Malay but they use Burma / Myanmar or language Rohingya often . This can cause difficulty to utter Malay somewhat. The respondents have to study Malay as it is the medium of instruction. When at home, respondents will resort either speaking in Burmese or Rohingya language with their family members and neighbors. In a nutshell, the environment plays an important role in teaching language skills. These findings support the findings of Siti Saniah (2012) which states that the learning environment is not helping foreign students to practice the national language. In fact, Kulthum (2003) also argues that the process of learning the Malay language should take place outside the classroom to expose students to speech in the real environment.

In general, students will find it difficult to master the spoken and written skills of the second language (Malay). In this regard, Nik Safiah Karim (1981) concluded that the language errors among students will continue to occur if students do not master the language in the sense of not understanding all aspects of the language, its grammatical aspects, and correct sentence structures. From the findings, the errors made by respondents 7 and 8 will affect their mastery in the Malay spoken language. According to Bhela (1999), when there is a large gap between the two languages (the mother tongue and the second language), there is a greater difficulty that a student has to face. 


\section{Conclusion}

The findings show that the errors in linguistic features of the speech of the Rohingya pupils are often attributed to the usage of abbreviations, prepositions, code-mixing, affixes and auxiliaries. Moreover, three factors that prevent Rohingya students from acquiring Malay language effectively are ignorance, environmental and language interference. The implication is that this study can benefit and contribute in the field of linguistics especially in the area of existing linguistic analysis. This is because, this study is still new to the researcher and ,thus far ,studies are scarce on Rohingya students. After all, the Rohingya is a small and new community living in Malaysia. This study is also beneficial for the UNCHR and school teachers in planning effective interventions to curb the problems of acquiring Malay language among the refugee students. Future studies should focus on teachers and stakeholders' insights on this matter.

\section{Acknowledgements}

We would like to thank Sekolah Pelangi Kasih administration, teachers and pupils for giving us opportunity and cooperation during the data collection of this study.

\section{References}

[1] Abdullah Hassan. (1982). General Linguistics for Bahasa Malaysia Teachers. Petaling Jaya: Publisher Fajar Bakti Sdn. Bhd.

[2] AFK Jilani. (2001). A Cultural History of Rohingya. Singapura: ISEAS Publishing.

[3] A.M. Thawnghmung. (2008). The Karan Revolution in Burma: Diverse Voices, Uncertain Ends. Singapura: ISEAS Publishing.

[4] Corder, S. P. (1971). Describing the language learner's language. CILT Reports and Papers, no. 6, 57-64.

[5] Corder, S. P. (1973). Introducing Applied Linguistics. Harmondsworth: Penguin Education.

[6] David I. Steinbergh. (2010). Burmal Myanmar What Everyone Needs to Know. New York: Oxford University Press.

[7] HLA PE. (1985). Burma Literature, Historiography, Scholarship, Language, Life, and Buddhism. Singapura: ISEAS Publishing.

[8] John F. Cady. (1978). A History of Modern Burma. United Kingdom: Cornell University Press.

[9] Letchamanan H. (2013). Myanmar's Rohingya Refugees in Malaysia: Education and the Way Forward. Journal of International and Comparative Education, 2:2.

[10] Md. Yunus. (1994). A History of Arakan. Bangladesh: Chittagong University Press.

[11] Md. Saddam Hossain \& Md. Sajjad Hosain. (2019). Rohingya Identity Crisis: A Case Study. Saudi Journal of Humanities and Social Sciences. Download on 10 Nov 2019 daripada: http://scholarsmepub. com/sjhss/

[12] Noor Aziah Haji Mohd Awal (2004). Religious Change: The Right to Care for Children - Issues and Problems. The Malayan Law Journal Articles, Volume 3.

[13] Puras D. (2015). Report of the special rapporteur on the right of everyone to the enjoyment of the highest attainable standard of physical and mental health. Human rights council, twenty-ninth session. Geneva: United Nations General Assembly. 